\title{
Assessment of factors affecting the intrinsic vulnerability of groundwater rated by the mean residence time estimation method
}

\author{
Robert DUDA ${ }^{1, *}$ and Paweł KOWALCZYK ${ }^{1}$ \\ 1 AGH University of Science and Technology, Faculty of Geology, Geophysics and Environmental Protection, \\ al. A. Mickiewicza 30, 30-059 Kraków, Poland
}

Duda, R., Kowalczyk, P., 2019. Assessment of factors affecting the intrinsic vulnerability of groundwater rated by the mean residence time estimation method. Geological Quarterly, 63 (1): 126-138, doi: 10.7306/gq.1454

Associate editor: Tatjana Solovey

We analyse the factors used for assessing groundwater intrinsic vulnerability to pollution in the mean residence time estimation method, providing a final vulnerability evaluation. The following factors were analysed: depth to shallow groundwater, effective precipitation infiltration coefficient, terrain inclination, volumetric water content of soils and rocks in the unsaturated zone and volumetric water content of the topsoil. GIS surveys were performed for two geomorphologically diverse regions: a highland piedmont and a lowland plain in Poland (Central Europe). In both cases, groundwater had spatially diverse vulnerability to contamination. The research method used relied on determining the percentage participation of the area with particular values of the parameters analysed in areas of different degrees of vulnerability. Knowledge of the extent and distribution of variability of the parameters analysed in areas of particular degrees of vulnerability helps explain the causes of spatial variation in groundwater intrinsic vulnerability to contamination in given areas.

Key words: groundwater vulnerability, intrinsic vulnerability, residence time, travel time, MRT, GIS.

\section{INTRODUCTION}

The intrinsic vulnerability of groundwater to contamination is affected by the depth to groundwater, net recharge (effective infiltration), impact of the vadose zone (lithology), soil media, the volumetric water content of the soils or rocks in the unsaturated zone, topography, aquifer media and hydraulic conductivity of soils or rock in aquifers. When groundwater occurs in karst and fractured-karst aquifers, the vulnerability value depends on the epikarst, protective cover and properties of overlying layers above the water table, infiltration conditions, precipitation, karst-network development and the concentration of flow (Doerfliger et al., 1999; Daly et al., 2002; Vias et al., 2006).

The participation of these parameters in the assessment of groundwater intrinsic vulnerability varies, therefore it is assumed in numerous rating methods, also called parametric methods or index methods of vulnerability evaluation, i.e. qualitative methods. In these methods, the influence of particular factors on the final vulnerability value results from individual weights and properly assumed rating scores. Although the results obtained with the index methods are qualitative, they are

\footnotetext{
* Corresponding author, e-mail: duda@agh.edu.pl
}

Received: August 24, 2018; accepted: January 8, 2019; first published online: March 14, 2019 still commonly used worldwide, especially via the very effective DRASTIC method (e.g., Krogulec, 2006; Różkowski, 2007; Saidi et al., 2011, 2017; Khemiri et al., 2013; Krogulec and Trzeciak, 2016). This method has been improved and adjusted to complex hydrogeological conditions (Witkowski et al., 2003; Yu et al., 2012; Jiménez-Madrid et al., 2013; Hernández-Espriú et al., 2014; Kazakis and Voudouris, 2015; Bonfanti et al., 2016; He et al., 2018). Combined methods generating a qualitative result are also used (Gemitzi et al., 2006; Civita, 2010).

Apart from qualitative methods, a purely quantitative method can be applied. It is based on the evaluation of a physical parameter, i.e. mean resident time (MRT), also called mean travel time (MTT), i.e. time in which water percolates with conservative solutes through the unsaturated zone. Conservative solutes neither change their concentration during their transport from the surface downwards to groundwater (e.g., in the course of biodegradation) nor undergo retardation (e.g., as a result of adsorption). The transport time is evaluated by assuming the "piston-flow" model, in which the conservative pollutant moves downwards at the average velocity of the percolating water (Bachmat and Collin, 1987; Hennings, 2000; Witczak et al., 2007; Wachniew et al., 2016). Mean denotes that the time value was not determined as a point but represents mathematically and spatially averaged values of particular factors accounted for in the estimation of time. The averaging is necessitated by the need to generalize the 3D variability of the unsaturated zone, i.e. heterogeneity and anisotropy, and also the hydrodynamic dispersion of the pollutant mass, which always occur in 
real conditions, and which vary spatially. More importantly, the groundwater vulnerability is spatially evaluated with GIS on contour maps, delineated on the basis of various data originally obtained of different scale, resolution and accuracy of measurement. The uncertainty level is considerable; therefore, we cannot be sure to determine the time, and so we only estimate this time. Analogous to the rating methods, this method also accounts for the spatial variability of parameters, and the use of GIS is inevitable.

The evaluation of groundwater vulnerability based on a time scale, i.e. a measurable physical parameter, allows one to easily and clearly assess or validate the result by using environmental tracers (Zuber et al., 2005, 2011; Newman et al., 2010; Wachniew, 2015; Hagedorn et al., 2018). Associated with land-use, indicating potential and real sources of contamination, this approach also shows the time in which the prevention measures can be planned and implemented (Bachmat and Collin, 1987). However, it is strongly burdened with subjectivity and essentially difficult to properly assume the MTR interval for particular intrinsic vulnerability degrees. This issue has not been finally agreed upon yet. Trying to be objective, Witczak et al. $(2007,2011)$ concentrated on the qualitative, descriptive classification of intrinsic vulnerability given by Foster et al (2002), assuming the following classification of intrinsic vulnerability: very high for $M R T<5$ years, high for MRT 5-25 years, moderate for MRT 25-50 years, low and very low for $M R T>50$ years. There was no evidence of fitting particular $M R T$ intervals to the classification provided by Foster et al. (2002). Witczak et al. (2011) assessed MRT with:

$$
M R T=M R T_{s}+M R T_{1}+M R T_{2}
$$

where: $M R T$ - the travel time of conservative solutes through of the unsaturated zone [years]; $M R T_{s}$ - the travel time of conservative solutes through topsoil [years]; $M R T_{1}$ - the travel time of conservative solutes through permeable soils and rocks [years]; $M R T_{2}-$ the travel time of conservative solutes through low-permeable soils [years]; and:

$$
M R T_{S}=\frac{1000 \times 1.5 \times \theta_{S}}{R}
$$

$$
\begin{gathered}
M R T_{1}=\frac{1000 \times\left[(d-1.5) \times\left(1-F_{l p}\right) \times \theta_{p}\right]}{R} \\
M R T_{2}=\frac{1000 \times\left[(d-1.5) \times F_{l p} \times \theta_{l p}\right]}{R}
\end{gathered}
$$

where: $\theta_{s}, \theta_{p}, \theta_{l p}$ - volumetric water content of: soil profile, permeable rocks and low-permeable rocks [dimensionless], respectively (see Table 1); $d$ - depth to groundwater [m], $F_{l p}$ - participation of low-permeable strata in the unsaturated zone, $R$ - average annual effective precipitation infiltration (i.e. recharge rate) [mm/a], 1000 recalculation measure coefficient, 1.5 - assumed topsoil profile thickness in metres.

The average annual effective precipitation infiltration, i.e. the recharge rate in the area analysed, can be determined with any method producing a spatially variable result, e.g. the infiltration coefficient method (Staśko et al., 2012; Tarka et al., 2017; Gumuła-Kawęcka et al., 2018). Witczak et al. (2011) estimated the recharge rate taking into account its spatial variability represented by a few parameters:

$$
R=P \times \alpha \times \beta \times \gamma \times \delta
$$

where: $P$ - average annual rainfall $[\mathrm{mm} / \mathrm{a}] ; \alpha$ - effective precipitation infiltration coefficient depending on the lithology of near-surface strata [-] (see Table 1); $\beta$-coefficient depending on the terrain inclination $[-] ; \gamma-$ coefficient depending on the land cover $[-] ; \delta-$ coefficient depending on the depth to groundwater [-].

A method based on the residence time (travel time) was also used in other groundwater intrinsic vulnerability assessments (Maxe and Johansson, 1998; Krogulec, 2006; Herrmann et al., 2012; Potrykus et al., 2018). Despite the differences in the vulnerability classification and the effect of particular factors taken into account in the methods compared, attempts were made to directly compare vulnerability results obtained with a quantitative

\begin{tabular}{|c|c|c|c|c|c|c|}
\hline \multicolumn{2}{|l|}{$\begin{array}{l}\text { Effective precipitation infiltration } \\
\text { coefficient [\%] }\end{array}$} & \multicolumn{3}{|c|}{$\begin{array}{l}\text { Volumetric water content of the soils and rocks } \\
\text { in the unsaturated zone [\%] }\end{array}$} & \multicolumn{2}{|l|}{$\begin{array}{l}\text { Volumetric water content } \\
\text { of the topsoil [\%] }\end{array}$} \\
\hline shales, siltstones, mudstones & 9 & \multirow{5}{*}{$\begin{array}{l}\frac{0}{0} \\
\frac{0}{\Phi} \\
\stackrel{\Xi}{\Xi} \\
\stackrel{\Xi}{\varrho}\end{array}$} & $\begin{array}{l}\text { granites, metamorphic } \\
\text { rocks, etc. }\end{array}$ & 1 & $\begin{array}{l}\text { loose sand, silty loose sand, } \\
\text { weakly loamy and silty sand }\end{array}$ & 12 \\
\hline $\begin{array}{l}\text { loams, landslide colluvia; } \\
\text { fractured rocks }\end{array}$ & 13 & & limestones, dolomites & 2 & $\begin{array}{l}\text { light loamy sand, silty sand, } \\
\text { sandy silt }\end{array}$ & 17 \\
\hline $\begin{array}{l}\text { loess, silts, sandy loams; sand- } \\
\text { stones, siltstones, mudstones }\end{array}$ & 15 & & sandstones, marls*, chalk* & 5 & light and silty loam, loamy silt & 24 \\
\hline sandstones & 17 & & sandy-gravel sediments & 10 & $\begin{array}{l}\text { medium and silty loam, heavy } \\
\text { and silty loam, clayey silt }\end{array}$ & 36 \\
\hline $\begin{array}{l}\text { sands, gravels and sandy loams } \\
\text { of terminal moraine }\end{array}$ & 22 & & silty and loamy sands & 20 & & \\
\hline $\begin{array}{l}\text { sands and gravels; very fractured } \\
\text { rocks - limestones, dolomites, } \\
\text { marls, sandstones }\end{array}$ & 26 & \multicolumn{2}{|c|}{ low permeable soils - loess, silts, loams } & 30 & & \\
\hline
\end{tabular}
method and the results of some rating methods (Ravbar and Goldscheider, 2009; Hermanowski and Ignaszak, 2017). There

T a ble 1

The values of some factors affecting groundwater vulnerability adopted by Witczak et al. (2011) to estimate the MRT

* - Witczak et al. (2011) assumed that in these rocks the downward transport of pollutants mainly takes place through the fractures, thus diffusion to the rock matrix can be ignored 
are also methods making use of numerical modeling to assess vulnerability through the age of water (Neukum and Azzam, 2009; Yu at al., 2014) as well as coupling travel-time estimation and the rating method (Pisinaras et al., 2016).

When assessing groundwater intrinsic vulnerability to pollution, the degree to which particular parameters of the MRTbased estimation participate in the range of areas of the given vulnerability degree is not usually analysed. Moreover, the degree of this participation can differ depending on the conditions of particular aquifer occurrence. The geomorphology of the area for which the groundwater vulnerability analysis was performed is one of the criteria on the basis of which conditions of aquifer occurrence were differentiated. Accordingly, this study is aimed at determining the participation of factors accounted for in the assessment of groundwater vulnerability with the MRT estimation method in the areas of given vulnerability degree, accounting for areas that are geomorphologically different. Knowledge concerning the values and the distribution of diversified participation of these parameters in areas of particular vulnerability degree will help explain and properly interpret causes of spatial differentiation of the intrinsic vulnerability of given aquifers.

\section{STUDY AREA}

The source material used in this investigation was the database and GIS project in which groundwater intrinsic vulnerability in Poland was assessed and mapped by Witczak et al. (2011). Two regions of different geomorphology were used for the analyses. The first of these (denoted as S) was the upper part of the Vistula River basin of upland and piedmont character with a surface of $43,109 \mathrm{~km}^{2}$ (Fig. 1). The other region (N) covered $32,301 \mathrm{~km}^{2}$ and is a part of the mainly agricultural Wielkopolska lowland. Both the upland-piedmont and lowland plain regions have geomorphological conditions typical of most land areas. The region $S$ is also geomorphologically diverse with fore-mountain highland $(\mathrm{H})$, upland $(U)$ and plain $(P)$.

The geomorphological diversity of the region $S$ results from its geological structure. In the south of the area, there are the Carpathians built of folded sandstones and shales (Cretaceous/Paleogene). A flat plain ( $P$ ) occurs in the area of the Carpathian Foredeep filled with Miocene deposits overlain by porous Quaternary deposits. The northern part is an upland $(U)$, which consists of old and partially eroded mountains built of fissured quartzite, limestones and dolomites (Cambrian/Devonian), as well as limestones and dolomites (Triassic/Jurassic). Within the area of $\mathrm{S}$, there is locally loess. The region $\mathrm{N}$ is covered by Pleistocene deposits - these are usually alternating layers of various types of fluvioglacial sands and loams.
The spatial variability and ranges of values of analysed factors used by Witczak et al. (2011) in the MRT estimation, i.e. depth to shallow groundwater, average annual precipitation, effective precipitation infiltration coefficient, terrain inclination, volumetric water content of the topsoil and water content of the soils and rocks in the vadose zone in regions $\mathrm{S}$ and $\mathrm{N}$ have been illustrated in Figures 2 and 3, respectively, and in Table 1. The values of these factors were not determined as part of the study described herein. The values of factors affecting the intrinsic vulnerability of groundwater given in Table 1 were adopted by Witczak et al. (2011) as typical of the values reported in the literature. The effective precipitation infiltration coefficient for soils and rocks is usually determined on the basis of empirical measurement in a lysimeter or in an approximate method of water balance in a catchment (Staśko et al., 2012). The volumetric water content of the topsoil, soils and rocks is usually determined by laboratory testing of soil or rock samples, or in the field by geophysical methods (Evett et al., 2008).

The values of factors affecting groundwater vulnerability which prevail in individual regions and sub-regions and the predominant degree of vulnerability are summarized in Table 2.

\section{METHOD}

In the GIS-based analyses, ranges of areas with particular groundwater vulnerability levels (very high, high, moderate, low) were determined for both study regions. Then the total surface area covered by particular vulnerability degrees was established for each of the areas. Subareas differing in values of particular factors accounted for in the MRT estimation were found in each area of given vulnerability level. The analyses covered such factors as depth to shallow groundwater, average annual precipitation, effective precipitation infiltration coefficient, terrain inclination, volumetric water content of the soils and rocks in the unsaturated zone and volumetric water content of the topsoil. Land cover was omitted in the analysis due to the large generalization of this factor's values established in the GIS project database, which was the source material for these studies (only three types of land cover were adopted).

There was then determined the total surface covering the subareas with particular values of a given parameter, including all areas where a given vulnerability level appeared. Finally, the percent cover of surface areas with particular values of analysed factors representing successive vulnerability levels was specified. This study was performed not on the basis of data from the testing (sampling) network but in GIS on the basis of area (spatial) data using ArcGIS and Quantum-GIS software.

Table 2

The values of factors affecting the groundwater vulnerability and the assessed degree of vulnerability which prevail in the regions analysed (based on Witczak et al., 2011)

\begin{tabular}{|l|c|c|c|}
\hline \multicolumn{1}{|c|}{ Factor } & \multicolumn{2}{c|}{ Region S } & \multirow{2}{*}{ Region N } \\
\cline { 2 - 4 } & sub-region H & sub-region P & sub-region U \\
\hline depth to groundwater [m] & $>20$ & $2-5$ & $10-20$ \\
\hline effective precipitation infiltration coefficient [\%] & 13 & 17 & 13 \\
\hline terrain inclination [degrees] & $>10^{\circ}$ & $0.5-2^{\circ}$ & $4-6^{\circ}$ \\
\hline volumetric water content of the topsoil [\%] & 24 & 24 & 24 \\
\hline water content of the soils and rocks in the vadose zone [\%] & 5 & 13 & 12 \\
\hline vulnerability & high & very high & very high \\
\hline
\end{tabular}




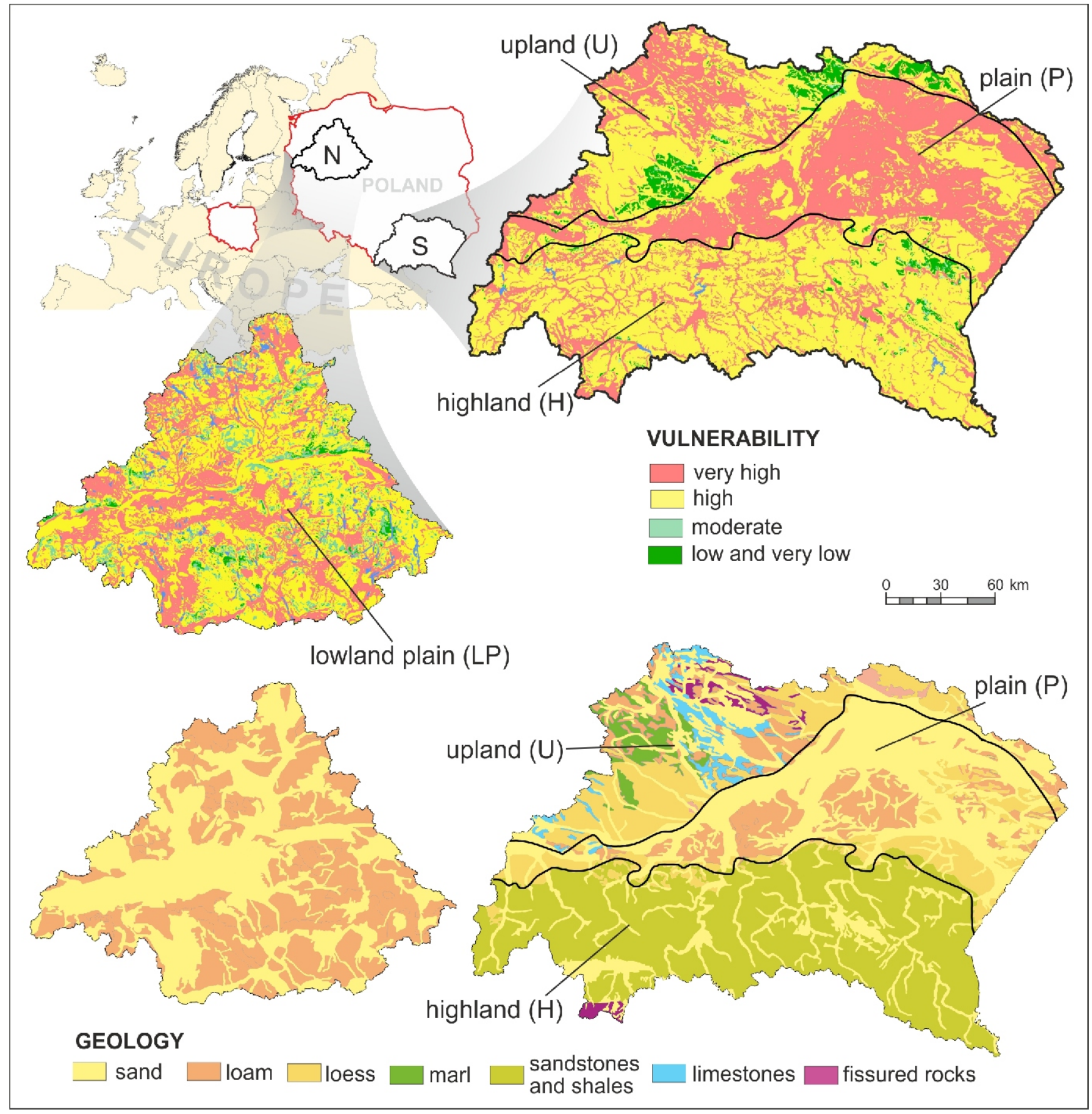

Fig. 1. Spatial variability of groundwater vulnerability to pollution in the regions $\mathbf{N}$ and $\mathbf{S}$ (based on Witczak et al., 2011) and geological sketch of these regions (based on Rühle et al., 1954, simplified)

Approximate boundaries of geomorphologically diverse sub-regions are marked in the region $\mathrm{S}$

\section{RESULTS AND DISCUSSION}

The spatial distributions of particular subareas with particular values of parameters affecting vulnerability in regions $S$ and $\mathrm{N}$ are shown, for example, in spatial range maps of borders of very high groundwater vulnerability areas (Figs. 4 and 5). In particular maps, areas are visible with values which most importantly affect this degree of vulnerability. This refers to a small depth to the groundwater table, higher values of effective precipitation infiltration coefficient and lower values of terrain incli- nation, volumetric water content of the topsoil, and soils and rocks in the unsaturated zone.

The participation of subareas with values of parameters affecting the vulnerability of areas of particular vulnerability degree in regions $S$ and $N$ is illustrated in Figures 6 and 7. Axis X1 represents degrees of intrinsic vulnerability, axis $\mathrm{X} 2$ represents parameter values, and axis $Y$ represents the percentage of surface areas with particular values of parameters in relation to the total surface area characterized by a given vulnerability degree. 


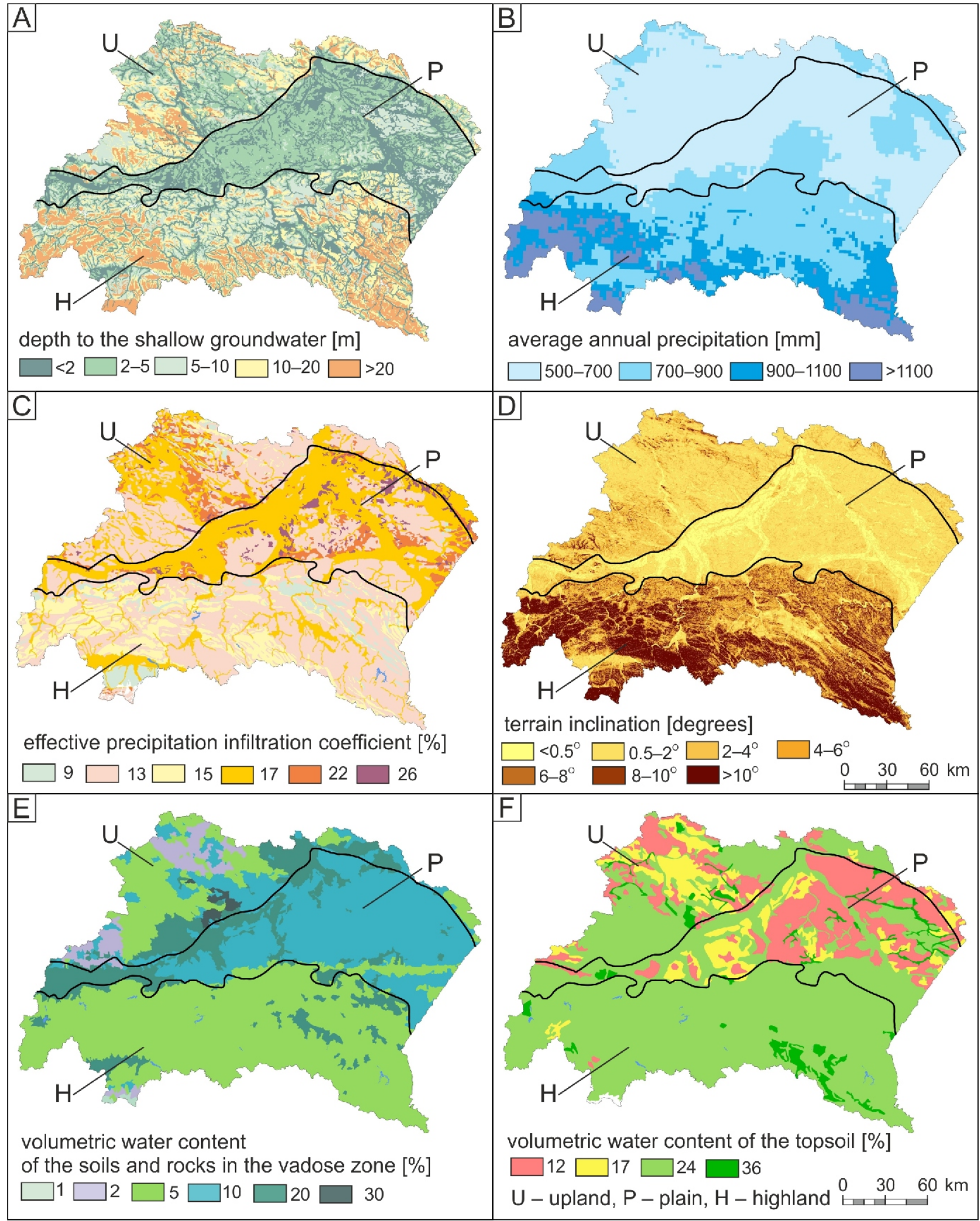

Fig. 2A-F - spatial distribution of factors affecting the groundwater vulnerability in region $\mathbf{S}$ (based on Witczak et al., 2011)

For values in panels $\mathrm{C}, \mathrm{E}$ and $\mathrm{F}$, see additional explanations in Table 1; boundaries of areas differing in geomorphology are approximate 
A

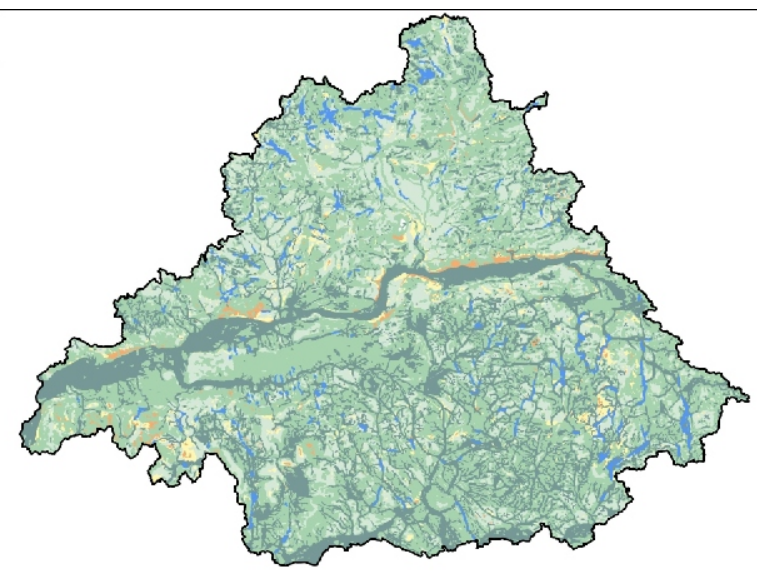

depth to the shallow groundwater [m] $\square<2 \square 2-5 \square$ 5-10 $\square$ 10-20 $\square>20$

C.

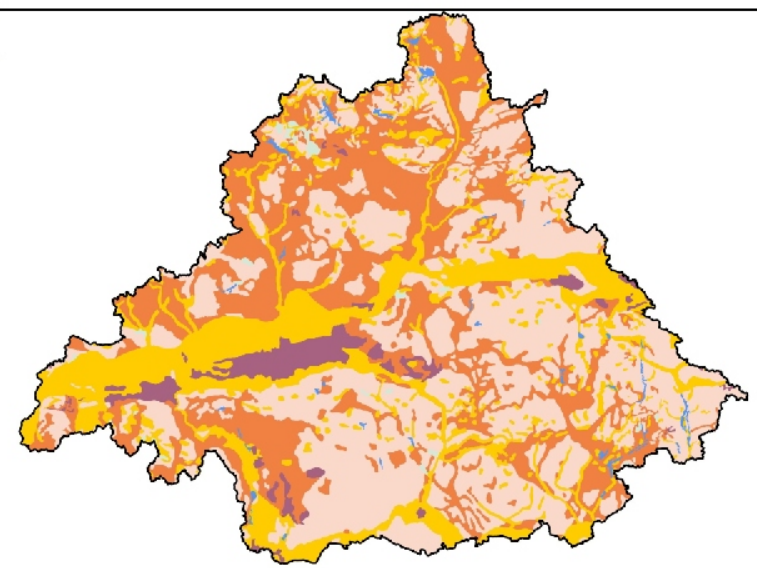

effective precipitation infiltration coefficient [\%]

\section{$\square 9 \square 13 \square 17 \square 22 \square 26$}

\section{E}

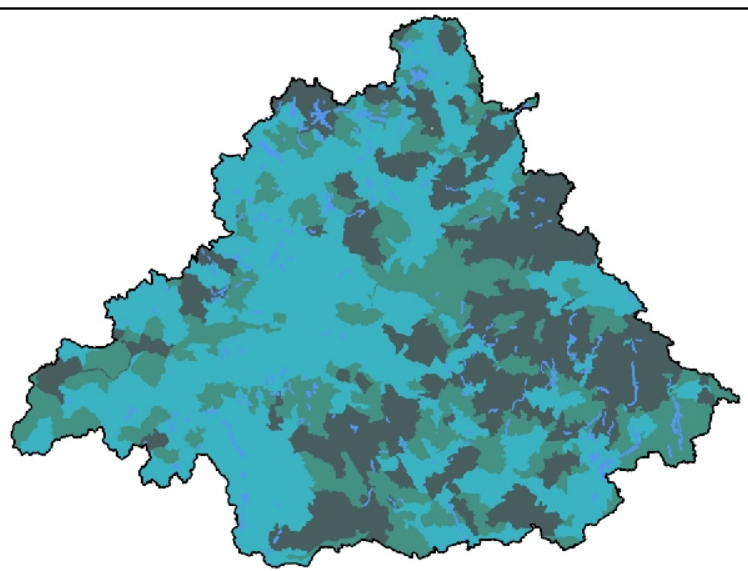

volumetric water content of the soils and rocks in the vadose zone [\%]
$10 \square 20 \square 30$
$0 \quad 30 \quad 60 \mathrm{~km}$

B

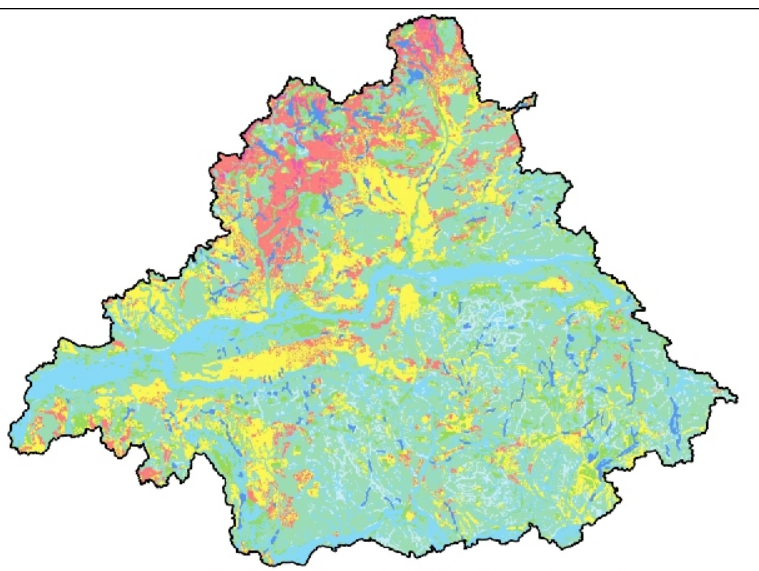

average annual effective infiltration [mm]

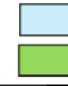

\section{D}

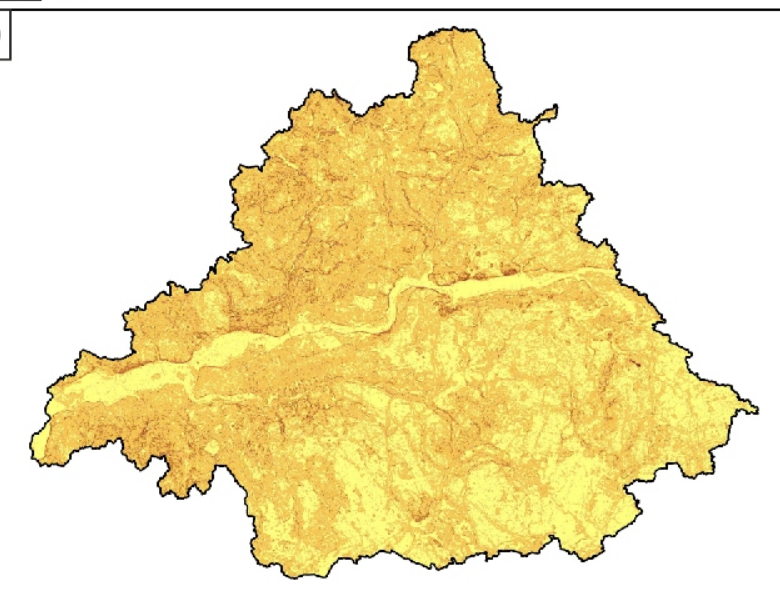

terrain inclination [degrees]

$\square<0.5^{\circ} \square 2-4^{\circ} \square 6-8^{\circ} \square>8^{\circ}$

F

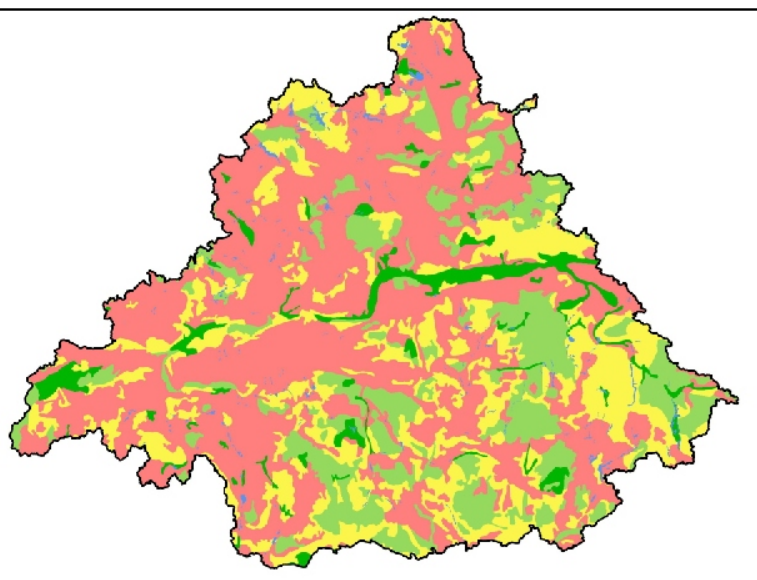

volumetric water content of the topsoil [\%]

$\square 12 \square 17 \square 24 \square 36$

Fig. 3A-F - spatial distribution of factors affecting the groundwater vulnerability in region $\mathrm{N}-$ the lowland plain (based on Witczak et al., 2011) 


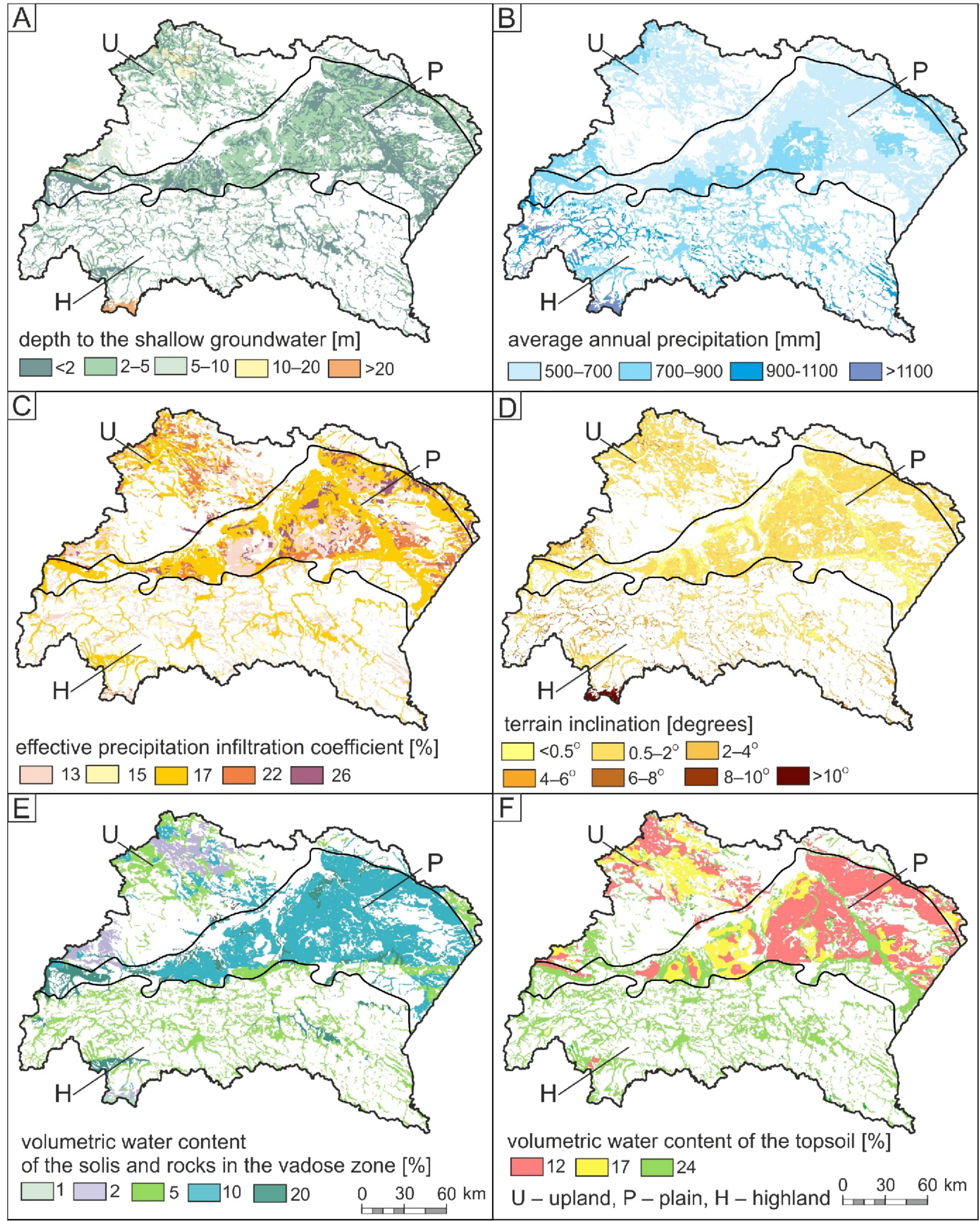

Fig. 4A-F - spatial range of subareas with particular values of factors affecting the vulnerability within areas of very high vulnerability - region S (based on Witczak et al., 2011)

White colour - areas where the vulnerability is other than very high; boundaries of areas of different geomorphology are approximate 


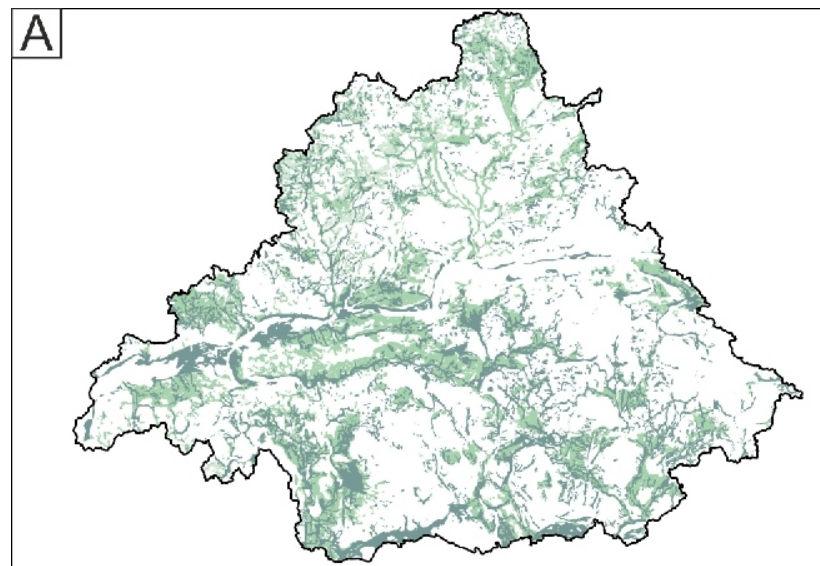

depth to the shallow groundwater [m]

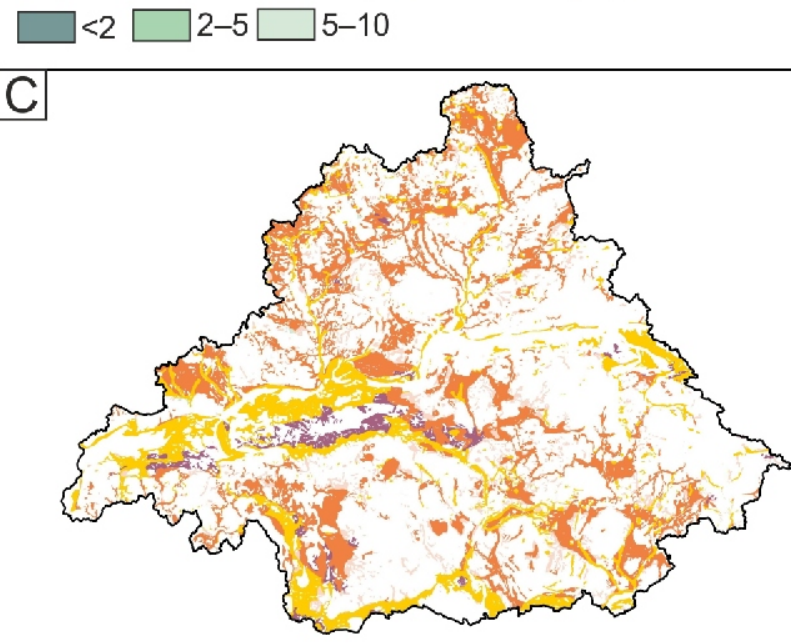

effective precipitation infiltration coefficient [\%]

$\square 13 \square 17 \square 22 \square 26$

\section{E}

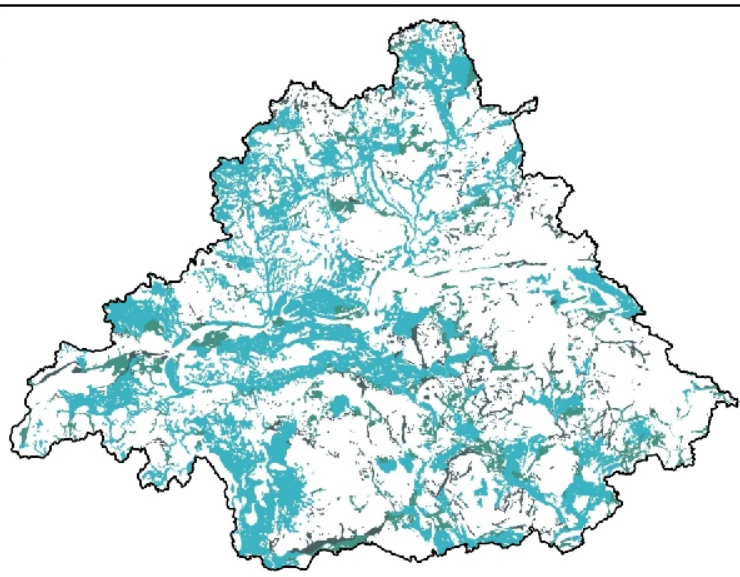

volumetric water content

of the solis and rocks in the vadose zone [\%]

$\square 10 \square 20 \square 30 \quad 0 \quad 30 \quad 60 \mathrm{~km}$

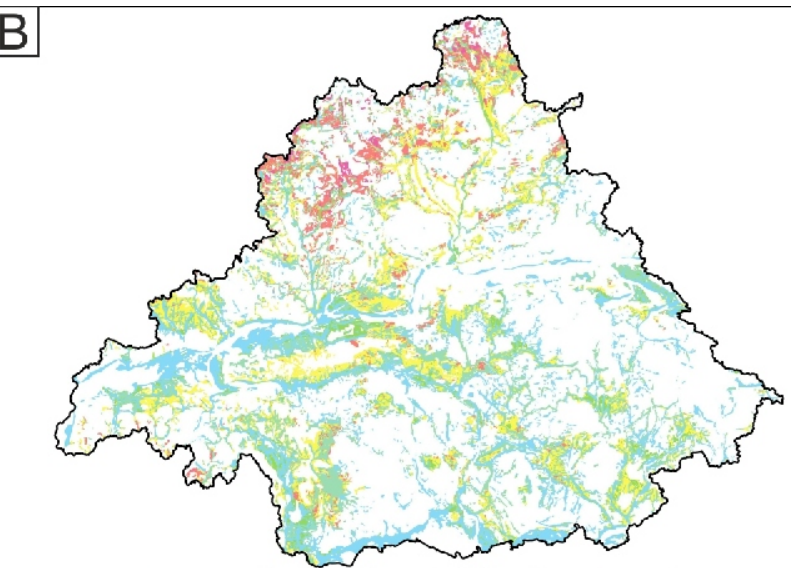

average annual effective infiltration [mm]

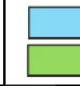

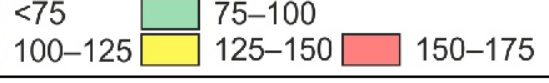

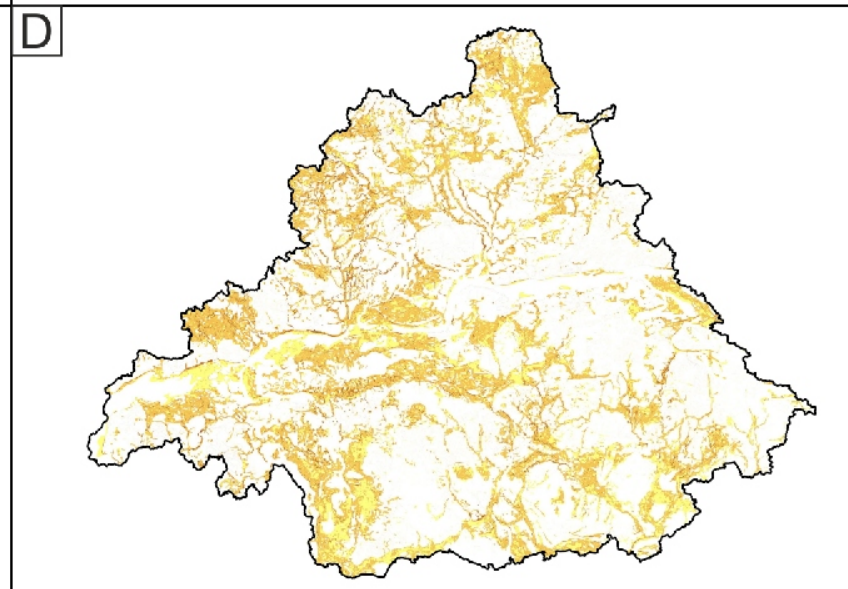

terrain inclination [degrees]

$\square<0.5^{\circ} \square 2-4^{\circ} \square 6-8^{\circ} \square>8^{\circ}$

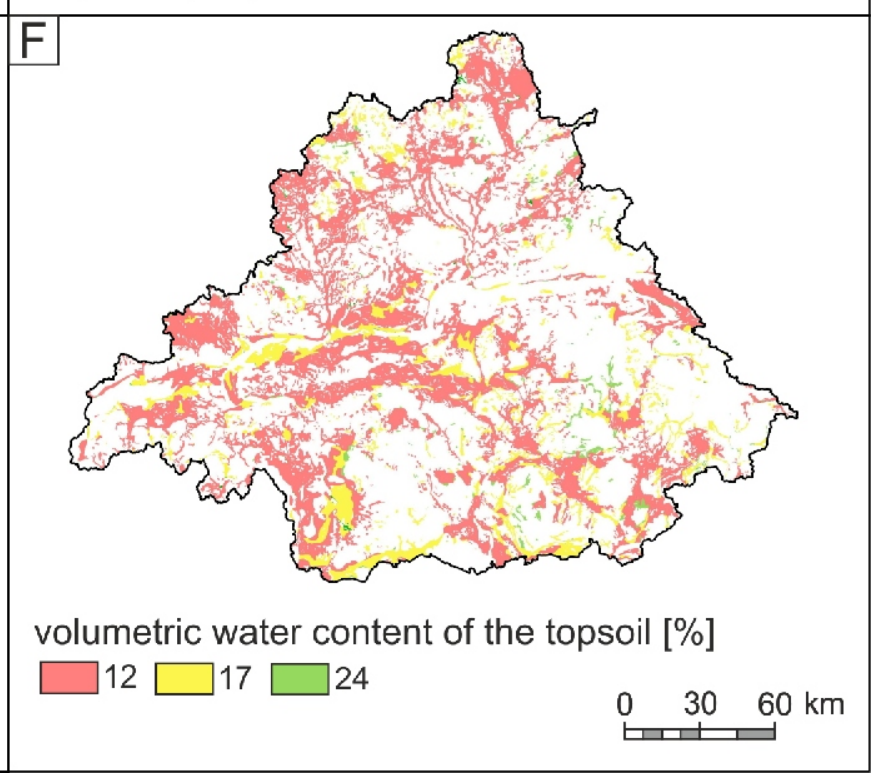

Fig. 5A-F - spatial range of subareas with particular values of factors affecting the vulnerability within areas of very high vulnerability - region $\mathbf{N}$ - lowland plain (based on Witczak et al., 2011) 

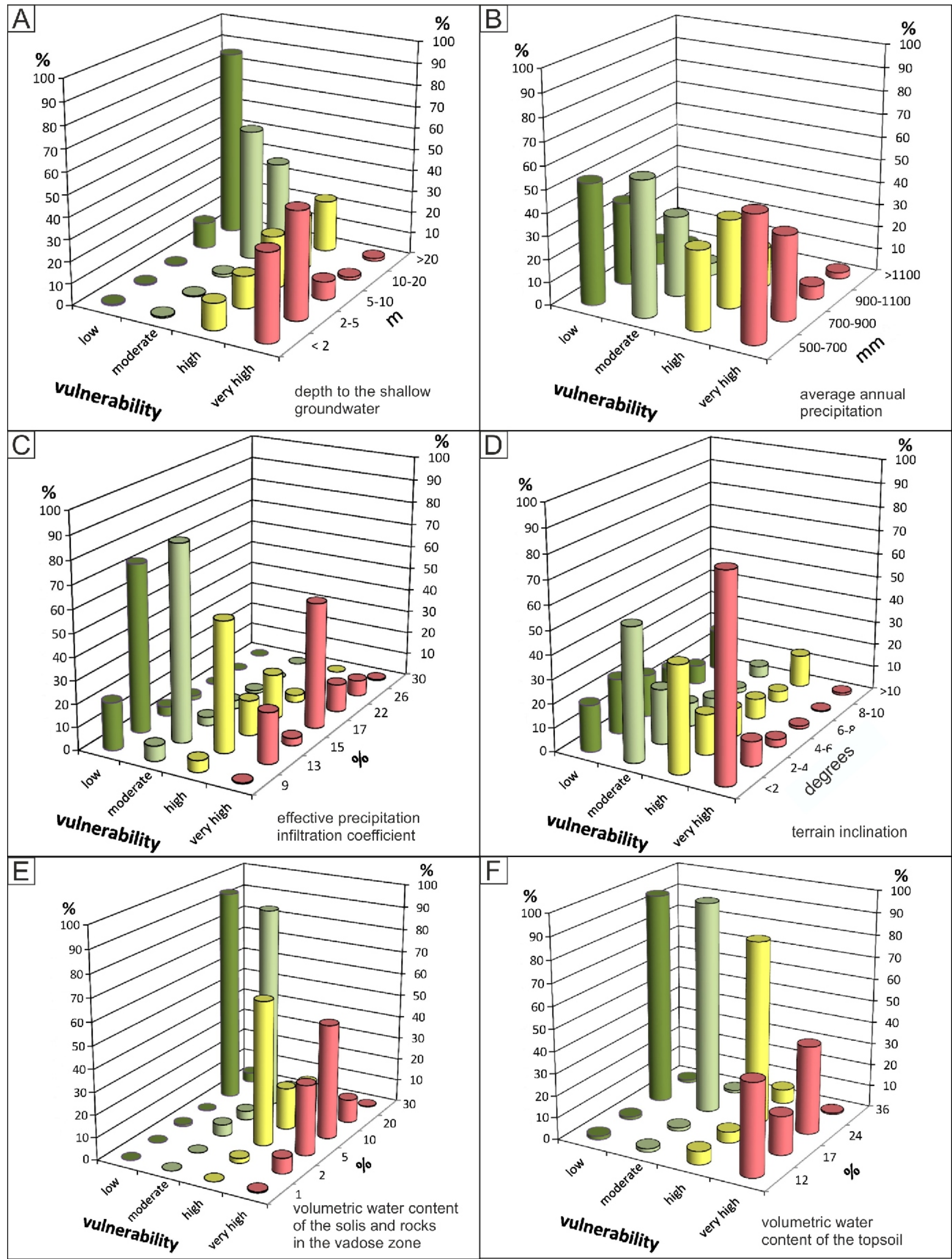

Fig. 6A-F - participation of subareas with particular values of factors influencing vulnerability in areas characterized by successive vulnerability degrees - region $S$ 

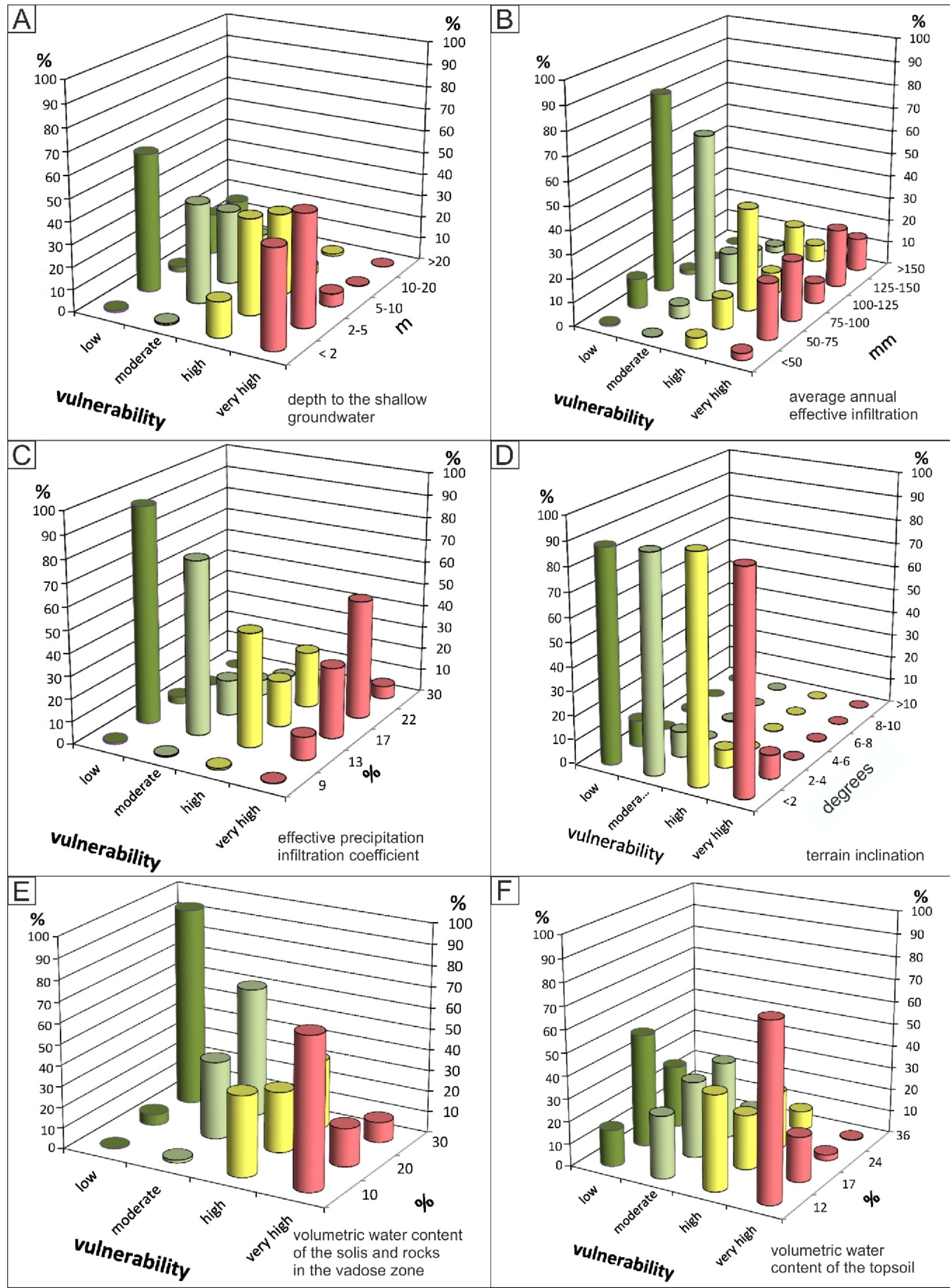

Fig. 7A-F - participation of subareas with particular values of factors influencing vulnerability in areas characterized by successive vulnerability degrees - region $\mathrm{N}$ 
The percentage of surface areas with particular depth intervals to the groundwater table in surface areas of particular vulnerability degree in regions $\mathrm{S}$ and $\mathrm{N}$ is shown in Figures $6 \mathrm{~A}$ and $7 \mathrm{~A}$. In areas with very high vulnerability, subareas where the depth is $<2 \mathrm{~m}$ and $2-5 \mathrm{~m}$ constitute 40 and $49 \%$ in region $\mathrm{N}$, and 44 and $50 \%$ in region $S$, respectively.

In areas of high vulnerability, the subareas with depths to groundwater of 5-10 m and 10-20 m constitute 24 and $25 \%$ in region $\mathrm{S}$, respectively. In region $\mathrm{N}$, depths of $2-5 \mathrm{~m}$ and $5-10 \mathrm{~m}$ were observed in 43 and $37 \%$ of surface areas with high vulnerability, respectively.

In areas of moderate vulnerability, subareas with depth to groundwater table of $10-20 \mathrm{~m}$ were noted in $60 \%$ of region S. In research region $N$, subareas with depths of $2-5 m$ and $5-10 m$ covered 44 and $33 \%$ of the surface, respectively. In region S, subareas with depth $>20$ m constituted $86 \%$ of the surface of areas with low vulnerability. However, in region $\mathrm{N}$, the depth interval of $2-5 \mathrm{~m}$ constituted $62 \%$ of the surface of areas with low vulnerability.

In region S, there was observed a relation between the participation of areas of particular depth intervals to the groundwater table and intrinsic vulnerability. The greater the participation of surfaces with large depths, the lower is the vulnerability. However, this dependence was not clearly observed in region $\mathrm{N}$, which may be the result of the specific character of the unsaturated zone in that area. This locally shows thick interbeds of low-permeable glacial loam.

The proportion of subareas of particular effective precipitation infiltration coefficient values in areas of successive vulnerability degrees in regions $\mathrm{S}$ and $\mathrm{N}$ is shown in Figures $6 \mathrm{C}$ and $7 C$, respectively. In areas of very high vulnerability, the subareas having near-surface sediments with an effective infiltration coefficient of 17 and $22 \%$ constitute 55 and $12 \%$ respectively of the surface area within region S, and 31 and $53 \%$ respectively within region $\mathrm{N}$. In areas of high vulnerability, subareas with an infiltration coefficient of 13 and $17 \%$ constitute 56 and $20 \%$ respectively of the surface area in region S, and 50 and $20 \%$ respectively in region $\mathrm{N}$. In areas of low vulnerability, where the near-surface sediments have this coefficient equal to 9 and $13 \%$, they constitute 21 and $73 \%$ within region $S$, and 1 and $96 \%$ within region $\mathrm{N}$, respectively.

A relation between areas with particular values of effective infiltration coefficient with their vulnerability was observed in both regions. The bigger is the proportion of area of low coefficient value, the lower is the groundwater vulnerability in that area.

The proportion of subareas with particular values of terrain inclination in areas characterized by successive vulnerability degrees in regions $S$ and $N$ is shown in Figures 6D and 7D. In very high vulnerability areas, subareas with terrain inclination $<2^{\circ}$ and $2-4^{\circ}$ constitute 84 and $10 \%$ of the surface area in region $\mathrm{S}$, and $90 \%$ and $10 \%$ in region $\mathrm{N}$, respectively. In high vulnerability areas, subareas with inclination angle $<2^{\circ}$ and $2-4^{\circ}$ constitute 44 and $17 \%$ surface area within region $S$, and 92 and $8 \%$ in region $N$, respectively. In region $S$, in the low vulnerability area, subareas with inclination angle $2-4^{\circ}$ and $4-6^{\circ}$ constitute 23 and $18 \%$ of the surface area, respectively.

In region S, there was observed a clear relation between the proportion of surfaces of subareas with a particular range of terrain inclination angle and their vulnerability degree. The smaller is the terrain inclination angle, the higher is the intrinsic vulnerability. In the lowland plain region $\mathrm{N}$, the vulnerability does not depend on the terrain inclination because the terrain inclination angles do not exceed $4^{\circ}$.

The proportion of subareas with particular volumetric water contents of soils and rocks in the unsaturated zone in areas characterized by successive vulnerability degrees in regions $S$ and $\mathrm{N}$ is shown in Figures $6 \mathrm{E}$ and $7 \mathrm{E}$, respectively. In region $\mathrm{S}$, subareas with soils having $20 \%$ volumetric water content (silty and loamy sands) constitute $90 \%$ of the surface area with moderate vulnerability and $95 \%$ of the surface area with low vulnerability. The subareas with soils having $10 \%$ volumetric water content (sands with gravel) constitute $51 \%$ of the surface of very highly vulnerable areas. The subareas with rocks of $5 \%$ volumetric water content (fractured sandstones, marls and chalk) constitute $64 \%$ of the surface area characterized by moderate vulnerability and $31 \%$ of the surface area with very high vulnerability.

In region $\mathrm{N}$, subareas with soils of $30 \%$ volumetric water content (loess, silts, loams) constitute $62 \%$ surface of areas of moderate vulnerability and $95 \%$ surface of areas of low vulnerability. The subareas with ground of $10 \%$ volumetric water content (sands with gravel) constitute $72 \%$ of the surface area of very high vulnerability. In both regions, with the increasing participation of surface subareas with higher volumetric water content values of soils and rocks in the unsaturated zone, the groundwater intrinsic vulnerability decreases.

The proportion of subareas with particular values of volumetric water content in topsoil in areas of successive vulnerability degrees in regions $S$ and $N$ is shown in Figures $6 \mathrm{~F}$ and $7 \mathrm{~F}$. In region S, the subareas with topsoil characterized by $24 \%$ volumetric water content constitute $40 \%$ of the surface area with very high vulnerability, $83 \%$ surface area with high vulnerability and $96 \%$ surface area of moderate and low vulnerability. The subareas with topsoil of volumetric water content of $12 \%$ constitute $42 \%$ of the surface area with very high vulnerability and only $2 \%$ surface of areas of moderate and low vulnerability.

In region N, the subareas with topsoil characterized by $24 \%$ volumetric water content constitute only $3 \%$ of the surface area with very high vulnerability, $26 \%$ surface of areas with high vulnerability, $34 \%$ surface of area with moderate and $28 \%$ surface of area with low vulnerability. The subareas with topsoil of $12 \%$ volumetric water content constitute $77 \%$ of the surface area with very high vulnerability and only $16 \%$ of the surface area with low vulnerability. In both regions, there is a relation between the increasing proportion of surface subareas with higher volumetric water content of topsoil and decreasing groundwater vulnerability to pollution.

The results of this preliminary study should be treated as approximate because the credibility of the data used is limited. This is mainly due to the high degree of generalization of input data used by Witczak et al. (2011) to develop the GIS project of the vulnerability map at 1:500,000 scale, i.e. at a reconnaissance scale. Consequently, assessment made of the spatial extents of particular values of factors affecting groundwater vulnerability but delineated with greater accuracy, e.g. at 1:50,000 or greater, may differ somewhat from the picture obtained in this study.

\section{CONCLUSIONS}

This investigation helped to explain the factors behind specific spatial ranges of given intrinsic groundwater vulnerability degrees assessed in both regions analysed by the MRT estimation method. A relation is shown between intrinsic groundwater vulnerability and some factors affecting this vulnerability. In the highland-piedmont region $\mathrm{S}$, as depth to groundwater increases, the vulnerability of the groundwater decreases, and that as the terrain inclination decreases, the vulnerability increases. In the region $\mathrm{N}$, these relationships were not observed, which may be due to it being a plain region where in the unsaturated zone there are interbeds of low-permeable loam and where there is no terrain inclination angle $>4^{\circ}$. 
In both regions of study, the intrinsic vulnerability of groundwater decreases with a decreasing value of effective precipitation infiltration coefficient. And, the groundwater vulnerability decreases with an increase in the volumetric water content of the soils and rocks in the vadose zone, as well as with increased water content of the topsoil.

In the highland-piedmont region S there was no clear correlation between the average annual rainfall and the susceptibility of groundwater to pollution. The reason may be that vulnerability depends on the groundwater recharge rate, and this in addition to the amount of rainfall also depends on the lithology of near-surface sediments and on the terrain inclination. A relation, albeit imprecise, between the vulnerability degree and the effective infiltration rate, i.e. recharge, was found in area $\mathrm{N}$ : with a decrease of the infiltration rate, the groundwater vulnerability decreases.

The geomorphological diversity of both regions, i.e. lowland plain and highland-piedmont, partly affects the vulnerability variability, but this factor is not crucial. The ambiguity of some of the results obtained reflects the fact that both specified vulnerability degrees and their spatial variability are a result of interac- tion of all factors affecting the intrinsic vulnerability assessment in a given area. Such an interaction of values of individual factors is a result of compensation of the sum of the effects generated by parameters increasing the vulnerability and lowering it. The 3D spatial distribution of individual factors usually strongly varies, and the degree of this variability usually increases as the surface of the analysed area increases, therefore it is difficult to clearly state which factor was decisive in the result of any given groundwater vulnerability assessment. Moreover, the results obtained will be affected by the fact that most of the MRT ranges used in the classification of groundwater intrinsic vulnerability were broad, i.e. 20 years (high vulnerability) and 25 years (moderate vulnerability).

Acknowledgements. This research was financially supported by the AGH University of Science and Technology under grant No. 11.11.140.797. The authors wish to thank all those involved in the review of this paper, especially Prof. J. Różkowski, for valuable remarks that significantly improved the value of this article.

\section{REFERENCES}

Bachmat, Y., Collin, M., 1987. Mapping to assess groundwater vulnerability to pollution. In: Vulnerability of Soil and Groundwater to Pollutants (eds. W. van Duijvenbooden and H.G. van Waegeningh), TNO Committee on Hydrological Research, Hague, Proceedings and Information, 38: 297-307.

Bonfanti, M., Ducci, D., Masetti, M., Sellerino, M., Stevenazzi, S. 2016. Using statistical analyses for improving rating methods for groundwater vulnerability in contamination maps. Environmental Earth Sciences, 75: 1003.

Civita, M.V., 2010. The combined approach when assessing and mapping groundwater vulnerability to contamination. Journal of Water Resource and Protection, 2: 14-28.

Daly, D., Dassargues, A., Drew, D., Dunne, S., Goldscheider, N., Neale, S., Popescu, I.C., Zwhalen, F., 2002. Main concepts of the "European approach" to karst-groundwater-vulnerability assessment and mapping. Hydrogeology Journal, 10: 340-345.

Doerfliger, N., Jeannin, P.-Y., Zwahlen, F., 1999. Water vulnerability assessment in karst environments: a new method of defining protection areas using a multi-attribute approach and GIS tools (EPIK method). Environmental Geology, 39: 165-176.

Evett, S., Cepuder, P., Heng, L.K., Hignett, C., Laurent, J.P., Ruelle, P., 2008. Field estimation of soil water content: a practical guide to methods, instrumentation and sensor technology. Training Course Series 30, International Atomic Energy Agency, Vienna.

Foster, S., Hirata, R., Gomes, D., D’Elia, M., Paris, M., 2002. Groundwater quality protection: a guide for water utilities, municipal authorities and environment agencies. The World Bank Washington, DC.

Gemitzi, A., Petalas, Ch., Tsihrintzis, V.A., Pisinaras, V., 2006. Assessment of groundwater vulnerability to pollution: a combination of GIS, fuzzy logic and decision making techniques. Environmental Geology, 49: 653-673.

Gumuła-Kawęcka, A., Szymkiewicz, A., Jaworska-Szulc, B., Pruszkowska-Caceres, M., Gorczewska-Langner, W., 2018. Preliminary estimation of groundwater recharge on Brda river outwash plain. $10^{\text {th }}$ Conference EKO-DOK 2018, E3S Web of Conferences, 44: 00050.

Hagedorn, B., Clarke, N., Ruane, M., Faulkner, K., 2018. Assessing aquifer vulnerability from lumped parameter modeling of modern water proportions in groundwater mixtures: application to California's South Coast Range. Science of the Total Environment, 15: 1550-1560.

He, H., Li X.-G., Li, X., Cui, J., Zhang, W., Xu, W., 2018. Optimizing the DRASTIC method for nitrate pollution in groundwater vulnerability assessments: a case study in China. Polish Journal of Environmental Studies, 27: 95-107.

Hennings, V., 2000. Methodendokumentation Bodenkunde: Auswertungsmethoden zur Beurteilung der Empfindlichkeit und Belastbarkeit von Böden. Geologisches Jahrbuch, Reihe G, Heft SG 1. Schweizerbartsche Verlagsbuchhandlung, Stuttgart.

Hermanowski, P., Ignaszak, T., 2017. Groundwater vulnerability based on four different assessment methods and their quantitative comparison in a typical North European Lowland river catchment (the Pliszka River catchment, western Poland). Geological Quarterly, 61 (1): 166-176.

Hernández-Espriú, A., Reyna-Gutiérrez, A., Sánchez-León, E., Cabral-Cano, E., Carrera-Hernández, J., Martínez-Santos, P., Macías-Medrano, S., Falorni, G., Colombo, D., 2014. The DRASTIC-Sg model: an extension to the DRASTIC approach for mapping ground water vulnerability in aquifers subject to differential land subsidence, with application to Mexico City. Hydrogeology Journal, 22: 1469-1485.

Herrmann, F., Berthold, G., Fritsche, J.G., Kunkel, R., Voigt, H.J., Wendland, F., 2012. Development of a conceptual hydrogeological model for the evaluation of residence times of water in soil and groundwater: the state of Hesse case study, Germany. Environmental Earth Sciences, 8: 2239-2250.

Jiménez-Madrid, A., Carrasco, F., Martínez, C., Gogu, R.C., 2013. DRISTPI, a new groundwater vulnerability mapping method for use in karstic and non-karstic aquifers. Quarterly Journal of Engineering Geology and Hydrogeology, 46: 245-255.

Kazakis, N., Voudouris, K.S., 2015. Groundwater vulnerability and pollution risk assessment of porous aquifers to nitrate: modifying the DRASTIC method using quantitative parameters. Journal of Hydrology, 525: 13-25.

Khemiri, S., Khnissi, A., Ben Alaya, M., Saidi, S., Zargouni, F., 2013. Using GIS for the comparison of intrinsic parametric methods assessment of groundwater vulnerability to pollution in scenarios of semi arid climate. The case of Foussana groundwater in the central of Tunisia. Journal of Water Resource and Protection, 5: 835-845. 
Krogulec, E., 2006. Methods and results of groundwater vulnerability evaluation to contamination in the Kampinoski National Park, central Poland. Acta Geologica Polonica, 56: 349-359.

Krogulec, E., Trzeciak, J., 2016. DRASTIC assessment of groundwater vulnerability to pollution in the Vistula floodplain in central Poland. Hydrology Research, 48: 1088-1099.

Maxe, L., Johansson, P.-O., 1998. Assessing groundwater vulnerability using travel time and specific surface area as indicators. Hydrogeology Journal, 6: 441-449.

Neukum, C., Azzam, R., 2009. Quantitative assessment of intrinsic groundwater vulnerability to contamination using numerical simulations. Science of the Total Environment, 408: 245-254.

Newman, B.D., Osenbruck, K., Aeschbach-Hertig, W., Solomon, D.K., Cook, P., Rozanski, K., Kipfer, R., 2010. Dating of "young" groundwater using environmental tracers: advantages, applications, and research needs. Isotopes in Environmental and Health Studies, 46: 259-278.

Pisinaras, V., Polychronis, Ch., Gemitzi, A., 2016. Intrinsic groundwater vulnerability determination at the aquifer scale: a methodology coupling travel time estimation and rating methods. Environmental Earth Sciences, 75: 85.

Potrykus, D., Gumuła-Kawęcka, A., Jaworska-Szulc, B., Pruszkowska-Caceres, M., Szymkiewicz, A., 2018. Assessing groundwater vulnerability to pollution in the Puck region (denudation moraine upland) using vertical seepage method. 10th Conference EKO-DOK 2018, E3S Web of Conferences, 44: 00147.

Ravbar, N., Goldscheider, N., 2009. Comparative application of four methods of groundwater vulnerability mapping in a Slovene karst catchment. Hydrogeology Journal, 17: 725-733.

Różkowski, J., 2007. Evaluation of intrinsic vulnerability of an Upper Jurassic karst-fissured aquifer in the Jura Krakowska (southern Poland) to anthropogenic pollution using the DRASTIC method. Geological Quarterly, 51 (1): 17-26.

Rühle, E., Sokołowski, S., Tyska, M., 1954. Mapa geologiczna Polski 1:1 000 000. Instytut Geologiczny, Warszawa.

Saidi, S., Bouri, S., Ben Dhia, H., Anselme, B., 2011. Assessment of groundwater risk using intrinsic vulnerability and hazard mapping: application to Souassi aquifer, Tunisian Sahel. Agricultural Water Management, 98: 1671-1682.

Saidi, S., Hosni, S., Mannai, H., Jelassi, F., Bouri, S., Anselme, B., 2017. GIS-based multi-criteria analysis and vulnerability method for the potential groundwater recharge delineation, case study of Manouba phreatic aquifer, NE Tunisia. Environmental Earth Sciences, 76: 511.

Staśko, S., Tarka, R., Olichwer, T., 2012. Groundwater recharge evaluation based on the infiltration method. International Association of Hydrogeologists, Selected Papers, 17: 189-197.
Tarka, R., Olichwer, T., Staśko, S., 2017. Evaluation of groundwater recharge in Poland using the infiltration coefficient method. Geological Quarterly, 61 (2): 384-395.

Vias, J.M., Andreo, B., Perles, M.J., Carrasco, F., Vadillo, I., Jimenez, P., 2006. Proposed method for groundwater vulnerability mapping in carbonate (karstic) aquifers: the COP method. Application in two pilot sites in Southern Spain. Hydrogeology Journal, 14: 912-925.

Wachniew, P., 2015. Environmental tracers as a tool in groundwater vulnerability assessment. Acque Sotterranee - Italian Journal of Groundwater, AS 13059: 19-25.

Wachniew, P., Zurek, A.J., Stumpp, Ch., Gemitzi, A., Gargini, A., Filippini, M., Rozanski, K., Meeks, J., Kværner, J., Witczak, S., 2016. Towards operational methods for the assessment of intrinsic groundwater vulnerability: a review. Critical Reviews in Environmental Science and Technology, 46: 827-884.

Witczak, S., Duda, R., Żurek, A., 2007. The Polish concept of groundwater vulnerability mapping. International Association of Hydrogeologists, Selected Papers on Hydrogeology, 11: 45-59.

Witczak, S., Duda, R., Żurek, A., Górski, J., Dragon, K. et al., 2011. Groundwater vulnerability map of Poland, 1:500 000 (in Polish with English translation). Ministry of Environment, Warszawa. Pub. by AGH University of Science and Technology, Krakow. https://www.mos.gov.pl/fileadmin/user_upload/mos/ srodowisko/geologia/publikacje/hydrogeologia/Mapa_wrazliwo sci_wod_podz_na_zaniecz-Podatnosc_lpoziomwod.pdf

Witkowski, A.J., Rubin, K., Kowalczyk, A., Różkowski, A., Wróbel, J., 2003. Groundwater vulnerability map of the Chrzanów karst-fissured Triassic aquifer (Poland). Environmental Geology, 44: 59-67.

Yu, C., Zhang, B.X., Yao, Y.Y., Meng, F.H., Zheng, C.M., 2012. A field demonstration of the entropy-weighted fuzzy DRASTIC method for groundwater vulnerability assessment. Hydrological Sciences Journal, 57: 1420-1432.

Yu, C., Yao, Y., Cao, G., Zheng, Ch., 2014. A field demonstration of groundwater vulnerability assessment using transport modeling and groundwater age modeling, Beijing Plain, China. Environmental Earth Sciences, 73: 5245-5253.

Zuber, A., Witczak, S., Różański, K., Śliwka, I., Opoka, M., Mochalski, P., Kuc, T., Karlikowska, J., Kania, J., Korczyński-Jackowicz, M., Duliński, M., 2005. Groundwater dating with $3 \mathrm{H}$ and SF6 in relation to mixing patterns, transport modelling and hydrochemistry. Hydrological Processes, 19: $2247-2275$.

Zuber, A., Różański, K., Kania, J., Purtschert, R., 2011. On some methodological problems in the use of environmental tracers to estimate hydrogeologic parameters and to calibrate flow and transport models. Hydrogeology Journal, 19: 53-69. 